\title{
The effect of linseed oil and of linseed oil fatty acids incorporated in the diet on the metabolism of sheep
}

\author{
By J. W. CZERKAWSKI, K. L. BLAXTER* aND F. W. WAINMAN* \\ Hannah Dairy Research Institute, Ayr
}

(Received ${ }_{5}$ September 1965-Accepted 2 May 1966)

\begin{abstract}
I. Three sheep were given three diets, a control diet consisting mainly of cereals, a similar diet incorporating linseed oil (mainly glycerides of linolenic acid) and a diet incorporating free fatty acids derived from linseed oil. The diets were given at the maintenance level and at twice this level according to a latin square design. 2. Complete energy balance was obtained and the digestibilities of cellulose and lipid were determined with each sheep receiving each diet. The relative amounts of various fatty acids in the dietary and faecal lipids were also estimated. 3. The inclusion of lipids in the diet resulted in a significant decrease in cellulose digestion, whereas the lipid digestibility increased. 4 . The proportion of $\mathrm{C}_{18}$ acids increased in the faeces, and the proportion of bacterial fatty acids decreased, but since the total amount of fatty acids excreted increased, the amount of bacterial fatty acids excreted per day did not differ significantly in animals receiving the control diet and the diets containing added lipids. 5. The addition of lipids to the diet resulted in a highly significant drop in methane production, the depression being about $25 \%$ of the control value. The depression ( $28.9 \mathrm{kcal} / \mathrm{roo} \mathrm{kcal}$ of fatty acids given) was considerably greater than the depression produced by continuous infusion of the same amount of fatty acids. 6 . Because of the depression of $\mathrm{CH}_{4}$ production and of some reduction in the urinary energy losses, the addition of lipids to the basal diet increased the metabolizable energy by about $9.5 \mathrm{kcal} / \mathrm{r} 00 \mathrm{~g}$ of the basal diet. 7. The efficiencies of utilization of metabolizable energy were not significantly affected by addition of lipids, being about $82 \%$ for maintenance and $62 \%$ for fattening. 8 . In an experiment with one sheep, comparison was made between the effect of slow continous infusion of fatty acids over $24 \mathrm{~h}$ and the effect of rapid infusion of the same amount twice daily during feeding. The continuous infusion of linseed oil fatty acids resulted in a drop in $\mathrm{CH}_{4}$ production of $16.3 \mathrm{kcal} / 100 \mathrm{kcal}$ of fatty acids given. This was in good agreement with previous findings. Rapid infusion of these fatty acids resulted in a drop in $\mathrm{CH}_{4}$ production, amounting to $28.0 \mathrm{kcal} / \mathrm{roo} \mathrm{kcal}$ of fatty acids infused. This is comparable with the reduction of $28.9 \mathrm{kcal} / \mathrm{I} 00 \mathrm{kcal}$ fatty acids when the fatty acids were incorporated in the diet.
\end{abstract}

When fat of plant or animal origin is added to the diets of ruminants, the apparent digestibility of the fibrous components of the diets is usually but not invariably depressed. Relevant experiments have been summarized in papers by Roberts \& McKirdy (1964), by Davison \& Woods (1960, 1963a) and by White, Grainger, Baker \& Stroud (1958). Buysse (1962) showed in experiments with sheep that the depression was evident only when more than $30-45 \mathrm{~g}$ fat were added to the diet. This represents about $5 \%$ of the diet and it is generally accepted that amounts of fat larger than about $7 \%$ of the diet are not tolerated by ruminants. The effect of fat on cellulose digestion appears most marked with diets of low-quality roughages and the depression is in part reversed by the addition of alfalfa ash or calcium (White $e$ t al. 1958; Davison $\&$ Woods, 196r, r963 $b$; Ward, Tefft, Sirny, Edwards \& Tillman, 1957).

When unsaturated long-chain fatty acids were infused at a constant rate into the rumens of sheep given diets of high-quality roughage (Czerkawski, Blaxter $\&$ Wain-

- Present address: The Rowett Research Institute, Bucksburn, Aberdeen. 
man, 1966), it was found that any increases in the energy of the faeces were almost entirely due to increases in their lipid content and that any increase in their cellulose content was very small. In one experiment $128 \mathrm{~g}$ linolenic acid were given. This amounted to $14 \%$ of the dietary dry matter, and faecal energy increased by only Ior $\mathrm{kcal} / \mathrm{day}$, an amount less than that expected from the increase in faecal lipid, and suggesting a slight improvement in the apparent digestibility of the basal diet. Slight improvement of the digestibility of the basal diet by steers had been noted previously by Esplin, Hale, Hubbert \& Taylor (1963) when $4 \%$ of tallow or of a mixture of vegetable and animal fat was added to the diet.

It has been suggested by Hungate (1962) that $\mathrm{CH}_{4}$ production is proportional to the total integrated bacterial activity in the rumen. When fatty acids were infused into the rumens of sheep given basal diets of dried grass, there were considerable depressions of $\mathrm{CH}_{4}$ production with but minor depressions of cellulose digestion (Czerkawski et al. 1966).

The experiments described below were undertaken to find whether reduction in $\mathrm{CH}_{4}$ output can be produced when lipids are incorporated into entirely different types of diet and the mixture given twice daily. Both glycerides and free fatty acids were used, since it was possible that in some of the feeding trials referred to above, the marked depressions of cellulose digestion might have been due to a slow rate of lipolysis in the rumen, and reflected an effect of glycerides rather than of fatty acids.

EXPERIMENTAL

Animals. Three wether sheep, F, E and B, trained to the respiration chambers, were used to determine the utilization of glycerides and fatty acids incorporated in the diet. A sheep, W, with a rumen fistula was used to study the utilization of linolenic acid given as an infusion.

'Table I. Chemical composition of the dry matter of the three diets

\begin{tabular}{lccccc}
\multicolumn{1}{c}{ Diet } & $\begin{array}{c}\text { Gross } \\
\text { energy } \\
(\mathrm{kcal} / \mathrm{g})\end{array}$ & $\begin{array}{c}\text { Crude } \\
\text { protein } \\
(\%)\end{array}$ & $\begin{array}{c}\text { Carbon } \\
(\%)\end{array}$ & $\begin{array}{c}\text { Cellulose } \\
(\%)\end{array}$ & $\begin{array}{c}\text { Lipid } \\
(\%)\end{array}$ \\
Control & $4 \cdot 42$ & $17 \cdot 8$ & $44 \cdot 3$ & $13 \cdot 4$ & $4 \cdot 0$ \\
Containing added glycerides & 4.53 & $16 \cdot 4$ & 45.2 & 12.9 & $8 \cdot 9$ \\
Containing added fatty acids & 4.57 & $17 \cdot 0$ & $45 \cdot 8$ & 12.6 & 8.5
\end{tabular}

Design. Sheep F, E and B received each of three diets in turn according to a latin square design. Two amounts of the diet were given, one calculated to provide about enough energy to maintain weight and the other twice this amount, the lower amount being given first. The eighteen experimental periods each lasted for 3 weeks. During the last 6 days of each period the sheep were kept in a respiration chamber where faeces and urine were collected and oxygen consumption, carbon dioxide and $\mathrm{CH}_{4}$ production were determined continuously.

The analyses of the faeces included determination of their dry-matter, carbon, $\mathrm{N}$, cellulose and lipid contents, the individual fatty acids in the lipid and the heat of 
combustion of the lipids. Urine was analysed for $\mathrm{C}$ and $\mathrm{N}$ and its heat of combustion measured. The calorimetric methods and analytical techniques used were those listed by Czerkawski $e$ t al. (1966).

Diets. A basal mixture of foods was used to make the three diets and consisted of: sugar-beet pulp $30 \%$, decorticated groundnut meal $20 \%$, barley meal $35 \%$, oatmeal $10 \%$ and ground oat husk $5 \%$. The high concentration of sugar-beet pulp was included in the basal mixture because, of all the foods examined in calorimetric experiments at this Institute, sugar-beet pulp resulted in the highest production of $\mathrm{CH}_{4}$ (Blaxter \& Clapperton, 1965).

The control diet was this basal mixture to which was added $\mathrm{I} \cdot 6 \mathrm{~kg}$ of a mineral mixture/100 kg, the mineral mixture being $\mathrm{I} \mathrm{kg} \mathrm{NaCl}, 0.5 \mathrm{~kg} \mathrm{CaHPO}$ and $0 . \mathrm{I} \mathrm{kg}$ $\mathrm{MgO}$. The glyceride diet was the basal mixture to which was added $\mathrm{I} \cdot 6 \mathrm{~kg}$ minerals and $5.0 \mathrm{~kg}$ linseed oil, and the fatty acid diet was the same as the glyceride diet except that linseed oil fatty acids replaced the linseed oil. All three diets were made into pellets. The composition of the diets and the fatty acid composition of the lipids of the linseed oil and the linseed oil fatty acids and of the lipids of the complete diets are shown in Tables $\mathrm{I}$ and 2.

Table 2. Composition of the fatty acids (\% by weight) of the linseed oil, the linseed oil fatty acids and of the fatty acids extracted from three diets

\begin{tabular}{|c|c|c|c|c|c|}
\hline \multirow[b]{2}{*}{$\begin{array}{l}\text { Fatty } \\
\text { acid }\end{array}$} & \multirow[b]{2}{*}{$\begin{array}{l}\text { Linseed } \\
\text { oil* }\end{array}$} & \multirow[b]{2}{*}{$\begin{array}{c}\text { Linseed } \\
\text { oil fatty } \\
\text { acids }\end{array}$} & \multicolumn{3}{|c|}{ Fatty acids extracted from: } \\
\hline & & & $\begin{array}{c}\text { Control } \\
\text { diet }\end{array}$ & $\begin{array}{l}\text { Diet } \\
\text { containing } \\
\text { added } \\
\text { glycerides }\end{array}$ & $\begin{array}{c}\text { Diet } \\
\text { containing } \\
\text { added } \\
\text { fatty acids }\end{array}$ \\
\hline $14: 0$ & - & - & Trace & 0.3 & 0.2 \\
\hline $15: 0$ & - & - & - & Trace & - \\
\hline I6:0 & $4 \cdot 5$ & $5 \cdot 4$ & II $\cdot 7$ & $7 \cdot 4$ & $8 \cdot 2$ \\
\hline $17: 0$ & - & - & - & Trace & - \\
\hline I8:0 & $4 \cdot 4$ & $4 \cdot 2$ & $4 \cdot 0$ & $3 \cdot 3$ & $2 \cdot 4$ \\
\hline $18: 1$ & 17.0 & 17.4 & $28 \cdot 8$ & $24 \cdot 6$ & $18 \cdot 2$ \\
\hline $18: 2$ & 15.5 & 13.8 & $37 \cdot 8$ & $25 \cdot 6$ & $25 \cdot 5$ \\
\hline $18: 3$ & $58 \cdot 6$ & $59^{\circ} \mathrm{I}$ & $12 \cdot 7$ & $3^{8 \cdot 9}$ & $34: 4$ \\
\hline $20: 0$ & - & - & Trace & Trace & - \\
\hline Unidentified $f$ & - & - & $5 \cdot 0$ & Trace & IIrO \\
\hline
\end{tabular}

The amounts of the control diet given were 600 and $I 200 \mathrm{~g} /$ day and of the diets containing glycerides and fatty acids 630 and $\mathrm{x} 260 \mathrm{~g} /$ day. These last two diets nominally supplied $30 \mathrm{~g}$ and $60 \mathrm{~g}$ glyceride or fatty acids derived from the additions of linseed oil and linseed oil fatty acids, the amount of basal mixture being the same as for the control diet. The sheep were given the diets in two meals. The pellets, as soon as they were made, were weighed into individual meals, placed in polythene bags and refrigerated at $4^{\circ}$. Samples taken throughout the storage period showed no evidence that any peroxidation of the fatty acids had taken place. When, 3 months after the 
completion of the experiment, the analysis of lipid content of the pellets was checked using samples stored under laboratory conditions, the recovery of lipid from the glyceride diet, but not from the fatty acid diet, was found to be about $10 \%$ low. It is thought that some polymerization of the oil had taken place in the interval.

Experiment with infused linseed oil fatty acids. Sheep W was given $900 \mathrm{~g}$ dried grass in two meals daily throughout the experiment. After 2 weeks of adjustment to the diet, the sheep was placed in a respiration chamber and metabolism measured daily for 60 consecutive days. Linseed oil fatty acids (60 g/day) half neutralized with $\mathrm{NaOH}$ were made into an emulsion in 21 . water and infused into the rumen during days 9-20 inclusive and from days 37 to 48 inclusive. On the first occasion the fatty acids were infused at the fast rate of $\mathrm{I}$ l. in $30 \mathrm{~min}$ at the same time (05.00 and $16.30 \mathrm{~h}$ ) that the animal was fed. On the second occasion the fatty acids were infused continuously at a constant rate of $21 . / 24 \mathrm{~h}$. The experiment enabled a comparison to be made of the effects of the same amounts of fatty acids given by the same technique either rapidly or slowly. The analytical and calorimetric techniques were those adopted in the experiments with sheep F, E and B.

\section{RESULTS}

Apparent digestibility of the diets. Table 3 summarizes the coefficients of apparent digestibility of the dry matter, energy, $\mathrm{N}$, cellulose and lipids of the three diets, the values being means of determinations made at both the low and high levels of feeding. The apparent digestibilities of dry matter, energy and $\mathrm{N}$ were very similar for all three diets. With the diets containing added glyceride, however, cellulose was significantly less well digested than cellulose in the control diet, while the digestibility of the total lipid increased. With the fatty acid diet also a fall in cellulose digestion occurred, but addition of fatty acids did not significantly increase the mean apparent digestibility of

Table 3. Apparent digestibility (\%) of three diets obtained in experiments with three sheep

(Each value is the mean of three determinations at a low and three at a high level of feeding)

\begin{tabular}{|c|c|c|c|c|c|}
\hline Diet & $\begin{array}{c}\text { Dry } \\
\text { matter }\end{array}$ & Nitrogen & $\begin{array}{c}\text { Gross } \\
\text { energy }\end{array}$ & Cellulose & Lipid \\
\hline $\begin{array}{l}\text { Control } \\
\text { Containing added glycerides } \\
\text { Containing added fatty acids }\end{array}$ & $\begin{array}{l}82 \cdot 3 \\
81 \cdot 8 \\
80 \cdot 6\end{array}$ & $\begin{array}{l}83 \cdot 9 \\
8 \mathbf{r} \cdot 3 \\
82 \cdot 2\end{array}$ & $\begin{array}{l}83 \cdot 1 \\
82 \cdot 2 \\
80 \cdot 0\end{array}$ & $\begin{array}{l}63 \cdot 0 \\
58 \cdot 3 \\
56 \cdot 3\end{array}$ & $\begin{array}{l}60 \cdot 2 \\
75 \cdot 8 \\
62 \cdot 2\end{array}$ \\
\hline $\mathrm{SE}$ of means & $\pm 0.68 \mathrm{NS}$ & $\pm I \cdot I$ I NS & $\pm 0.86 \mathrm{NS}$ & $\pm I \cdot 82 *$ & $\pm 3.38 *$ \\
\hline
\end{tabular}

NS, not statistically significant.

* Statistically significant from control diet when $0.05>P>0.0$.

the total lipid of the diet. This was entirely due to the results obtained with sheep F which apparently digested only $32 \%$ of the total dietary lipid when given the high amount of the fatty acid diet. It digested $65 \%$ of the total lipid when given the low amount of diet.

Composition of the fatty acids from faecal lipid. Table 4 shows the mean percentage composition of the fatty acids isolated from the faecal lipids. There were no systematic 
effects of the level of diet and the results are expressed as the means of six experiments. The most obvious change in composition was an increase in the amounts of both saturated and unsaturated $\mathrm{C}_{18}$ acids with the diets containing linseed oil glycerides or fatty acids compared with those noted when the control diet was given. In addition, the percentages of uneven numbered and branched-chain acids and of palmitic acid fell with the diets containing added lipids. Since the total amount of fatty acid in the faeces increased with the diets containing added glycerides the amounts of these branched-chain fatty acids which could possibly be of bacterial origin did not change greatly. When the larger amount of the control diet was given, however, $1 \cdot 4 \mathrm{~g}$ of branched-chain and odd carbon number acids were excreted. This amount was considerably greater than the mean of $0.12 \pm 0.05 \mathrm{~g}$ /day observed when a diet of dried grass was given in previous experiments (Czerkawski et al. I966), a fact which possibly reflects differences in the bacterial flora of the lower gut of animals receiving these very different diets.

Table 4. Mean percentage composition of the fatty acids isolated from the faecal lipids of three sheep given the three diets

(The results in each column represent the mean of six experiments*)

\begin{tabular}{|c|c|c|c|}
\hline Fatty acids & $\begin{array}{c}\text { Control } \\
\text { diet }\end{array}$ & $\begin{array}{c}\text { Diet } \\
\text { containing } \\
\text { added } \\
\text { glycerides }\end{array}$ & $\begin{array}{l}\text { Diet } \\
\text { containing } \\
\text { added } \\
\text { fatty acids }\end{array}$ \\
\hline
\end{tabular}

Saturated acids mainly of dietary or tissue origin $\dagger$

$\begin{array}{rrrr}14: 0 & 1 \cdot 6 & 1.0 & 2 \cdot 0 \\ 16: 0 & 19.2 & 15.0 & 15 \cdot 2 \\ 18: 0 & 32.6 & 48.3 & 48 \cdot 4 \\ 20: 0 & 2.8 & 1 \cdot 7 & 1.8\end{array}$

Unsaturated acids mainly of dietary or tissue origin

$\begin{array}{lrrr}18: 1 & 10.9 & 11.9 & 14 \cdot 0 \\ 18: 2 & 4.1 & 5.1 & 4.4 \\ 18: 3 & 0.5 & 1.3 & 1.1 \\ 20: 1 & 0.0 & 0.3 & 0.0\end{array}$

Acids probably of bacterial origin

$\begin{array}{cccc}\text { 14:0 branched } & 0 \cdot 2 & \text { Trace } & 0 \cdot 0 \\ \text { 15:0 branched } & 3 \cdot 1 & 1 \cdot 6 & 2 \cdot 2 \\ \text { 15:0 } & 5 \cdot 7 & 3 \cdot 3 & 2 \cdot 3 \\ \text { 16:0 branched } & 0 \cdot 9 & 0 \cdot 4 & 0 \cdot 5 \\ \text { 17:0 branched } & 7 \cdot 0 & 3 \cdot 9 & 3 \cdot 4 \\ \text { 17:0 } & 4 \cdot 7 & 2 \cdot 6 & 2 \cdot 0 \\ \text { Unidentified* } & 4.1 & 1 \cdot 7 & 1 \cdot 7\end{array}$

* The sums of the columns do not add to I00\% because very small amounts of $\mathrm{C}_{12}, \mathrm{C}_{13}$ and acids higher than $\mathrm{C}_{20}$ have been ignored.

$\uparrow$ Palmitic acid may well be partly of bacterial origin.

Loss of energy as $\mathrm{CH}_{4}$. Table 5 summarizes the results for the production of $\mathrm{CH}_{4}$ by the sheep. As expected, the inclusion of sugar-beet pulp in the basal diet resulted in a high production of $\mathrm{CH}_{4}$. For the control diet at the low level of feeding this was I I. $\mathrm{kcal} \mathrm{CH}_{4} / \mathrm{I} 00 \mathrm{kcal}$ of food given. From the results obtained by Blaxter \& 
Clapperton (1965) a roughage diet with an apparent digestibility of $82 \%$ can be expected to result in production of $8.5 \pm 0.8 \mathrm{kcal} \mathrm{CH} / \mathrm{roo} \mathrm{kcal} \mathrm{food} \mathrm{at} \mathrm{a} \mathrm{maintenance}$ level of feeding, whereas sugar-beet pulp given as the sole constituent of the food can be expected to give a production of $10.8 \mathrm{kcal} / 100 \mathrm{kcal}$ at the maintenance level of feeding.

The addition of the lipids to the control diet resulted in a highly significant $(P<0.00 \mathrm{I})$ fall in $\mathrm{CH}_{4}$ production. The depression was about $25 \%$ in both instances. Calculated for $100 \mathrm{kcal}$ added lipid, the depression in $\mathrm{CH}_{4}$ production was 25.5 $\mathrm{kcal} / \mathrm{I} 00 \mathrm{kcal}$ with the diet containing added glycerides and $28.9 \mathrm{kcal}$ with the added fatty acids. Both values were considerably greater than the $16 \mathrm{kcal} / \mathrm{roo} \mathrm{kcal}$ fatty acid noted when linseed oil fatty acids or a similar preparation containing linolenic acid were infused continuously into the rumens of sheep (Czerkawski et al. i966).

\begin{tabular}{|c|c|c|c|}
\hline & & \multicolumn{2}{|c|}{$\mathrm{CH}_{4}$ produced } \\
\hline Diet & $\begin{array}{l}\text { Level of } \\
\text { feeding }\end{array}$ & (kcal/day) & $\begin{array}{l}\text { (kcal/1 } 100 \mathrm{kcal} \\
\text { food given) }\end{array}$ \\
\hline Control & $\begin{array}{l}\text { Low } \\
\text { High }\end{array}$ & $\begin{array}{l}249 \\
452\end{array}$ & $\begin{array}{l}11.02 \\
10.00\end{array}$ \\
\hline Containing added glycerides & $\begin{array}{l}\text { Low } \\
\text { High }\end{array}$ & $\begin{array}{l}194 \\
332\end{array}$ & $\begin{array}{l}7 \cdot 99 \\
6 \cdot 85\end{array}$ \\
\hline Containing added fatty acids & $\begin{array}{l}\text { Low } \\
\text { High }\end{array}$ & $\begin{array}{l}173 \\
329\end{array}$ & $\begin{array}{l}6 \cdot 99 \\
6 \cdot 65\end{array}$ \\
\hline SE of means & $\begin{array}{l}\text { Low } \\
\text { High }\end{array}$ & $\begin{array}{c} \pm 5^{\prime} 1^{* *} \\
\pm 20 \cdot 8^{*}\end{array}$ & $\begin{array}{l} \pm 0.22^{* *} \\
\pm 0.44^{*}\end{array}$ \\
\hline
\end{tabular}

Urine energy. The mean heat of combustion of the urine/ $100 \mathrm{kcal}$ food ingested was $5.5 \mathrm{I}$ for the control diet, 4.53 for the diet containing added glycerides and 4.77 $\mathrm{kcal} / \mathrm{r} 00 \mathrm{kcal}$ food for that containing added fatty acids. The differences between these quantities were statistically significant $(0.05>P>0.01)$.

Metabolizable energy of the diets. The mean metabolizable energies of the three diets were $67 \cdot \mathrm{I}, 70 \cdot 3$ and $68.4 \mathrm{kcal} / \mathrm{roo} \mathrm{kcal}$ food given for the control diet and those containing added glycerides and fatty acids respectively. The metabolizable energy of the total diet was increased by the addition of glycerides but only slightly increased by the addition of fatty acids to the basal diet.

Since each diet contained the same amount of the basal mixture of feeds, that is the difference between them was simply the addition of lipids, the effect of the additions on the loss of energy in faeces, urine and as $\mathrm{CH}_{4}$ can be calculated directly. This has been done in Table 6 where the determined losses of energy have been expressed per I00 $\mathrm{g}$ control diet. Table 6 shows that the faecal loss of energy when the glycerides were added to $100 \mathrm{~g}$ basal diet increased by $9.9 \mathrm{kcal}$. Lipid excretion increased by $4.6 \mathrm{kcal}$, so it can be concluded that materials with a heat of combustion of $5.3 \mathrm{kcal}$ 
were excreted in the faeces as carbohydrate and protein when $5.0 \mathrm{~g}$ glycerides were added to roo $\mathrm{g}$ of basal diet. While it is possible that the lipids of the basal diet were less well digested when glycerides were added, it appears probable that the figure of $5.3 \mathrm{kcal} / \mathrm{roO} \mathrm{g}$ basal diet is a true measure of the depression of the digestibility of the basal diet by the addition of glyceride. Precisely the same depression was noted when fatty acids were added to the diet. Of the increase in the non-lipid energy in the faeces, about $60 \%$ was accounted for by cellulose and about $30 \%$ by protein. The energy excreted in the urine was depressed by the glyceride and fatty acid additions and so was $\mathrm{CH}_{4}$ production, the sum of the two depressions being $14.7 \mathrm{kcal} / \mathrm{ro0} \mathrm{g}$ basal diet for the glyceride addition and $14.9 \mathrm{kcal} / \mathrm{roO} \mathrm{g}$ basal diet for the fatty acid diet. The depression in $\mathrm{CH}_{4}$ production on adding lipids was considerably greater than the depression of the digestibility of the basal diet, and the addition of the lipids thus increased the metabolizable energy of the basal diet by $9 \cdot 4-9 \cdot 6 \mathrm{kcal} / \mathrm{roO} \mathrm{g}$.

Table 6. Mean losses of energy in faeces, urine and as methane per 100 $g$ basal diet given to three sheep in six experiments, and the effects on these losses of adding linseed oil glycerides or fatty acids

\begin{tabular}{|c|c|c|c|c|c|}
\hline \multirow[b]{3}{*}{ Source of energy } & \multicolumn{3}{|c|}{ Dict } & & \\
\hline & \multirow[b]{2}{*}{$\begin{array}{l}\text { Control } \\
\text { diet }\end{array}$} & \multirow{2}{*}{$\begin{array}{l}\text { Diet } \\
\text { containing } \\
\text { added } \\
\text { glycerides }\end{array}$} & \multirow{2}{*}{$\begin{array}{l}\text { Diet } \\
\text { containing } \\
\text { added } \\
\text { fatty } \\
\text { acids }\end{array}$} & \multicolumn{2}{|c|}{ Change due to } \\
\hline & & & & $\begin{array}{c}\text { Glycerides } \\
(5 \circ \mathrm{g})\end{array}$ & $\begin{array}{l}\text { Fatty } \\
\text { acids } \\
(5 \circ \mathrm{g})\end{array}$ \\
\hline Faeces, total & $74 \cdot 3$ & $84 \cdot 2$ & $97 \cdot 7$ & +9.9 & $+23 \cdot 4$ \\
\hline Lipids in faeces* & 147 & $19 \cdot 3$ & $32 \cdot 8$ & +4.6 & $+18 \cdot 1$ \\
\hline Non-lipid in faeces & $59 \cdot 6$ & 64.9 & 649 & $+5 \cdot 3$ & $+5 \cdot 3$ \\
\hline Cellulose in faeces $\uparrow$ & $20 \cdot 6$ & $24 \cdot 2$ & $24 \cdot 3$ & $+3 \cdot 6$ & $+3 \cdot 7$ \\
\hline Protein in faecest & $13 \cdot 6$ & $15 \cdot 1$ & $15 \cdot 3$ & $+1 \cdot 5$ & $+1 \cdot 7$ \\
\hline Other carbohydrates in faeces & $25 \cdot 4$ & $25 \cdot 6$ & $25 \cdot 3$ & +0.2 & -0.1 \\
\hline Urine & $24 \cdot 0$ & $20 \cdot 8$ & $22 \cdot 1$ & $-3 \cdot 2$ & $-1 \cdot 9$ \\
\hline $\begin{array}{l}\mathrm{CH}_{4} \\
\text { Metabolizable energy of basal } \\
\text { diet }\end{array}$ & 45.7 & $34^{2}$ & $\begin{array}{c}32 \cdot 7 \\
-\end{array}$ & $\begin{array}{l}-11.5 \\
+\quad 9.4 \$\end{array}$ & $\begin{array}{l}-13.0 \\
+9.6\end{array}$ \\
\hline $\begin{array}{l}\text { - } 9.0 \mathrm{kcal} / \mathrm{g} \text { lipid. } \\
+4.2 \mathrm{kcal} / \mathrm{g} \text { cellulose. } \\
\pm 30.0 \mathrm{kcal} / \mathrm{g} \mathrm{N} \text {. } \\
\S \text { Algebraic sum of energy } \\
\text { eversed sign. }\end{array}$ & 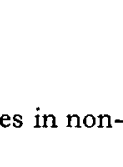 & & & & \\
\hline
\end{tabular}

Heat production, energy and $N$ retention. Table 7 summarizes the results of the determinations of heat production, energy retention and $\mathrm{N}$ retention. Heat production was not significantly affected by the addition of lipids to the diet though at the high level of feeding more heat was produced when lipids were added to the control. Energy retention was significantly greater with the diets containing added lipid than with the control diets. Differences between the diets in the $\mathrm{N}$ retention they promoted were not statistically significant. Urinary $\mathrm{N}$ excretion was lower in the six determinations made with the diet containing added glycerides and in five of the six determinations with the diet containing added fatty acids than in the six determinations with the control diet; the high errors attached to the retentions of $\mathrm{N}$ in Table 7 
largely arose from variation in the faecal loss of $\mathrm{N}$ on addition of lipids to the control diet.

From the results of the individual determinations of energy metabolism for each diet and determinations of the fasting heat production of the same sheep made on previous occasions, the efficiency of utilization of the metabolizable energy of the diets was calculated. The efficiencies of utilization of energy for maintenance were for the control diet $80.3 \%$, the diet containing added glycerides $82.9 \%$ and the diet containing added fatty acids $82 \cdot \mathrm{I} \%$, each efficiency having a standard error of $\pm \mathrm{I} \cdot 2 \%$. The efficiencies of utilization of metabolizable energy for fattening were $58 \cdot 5,62 \cdot 0$ and $63.4 \%$ for the control diet and diets containing added glycerides and fatty acids respectively, standard errors of means being $\pm 3.3 \%$. Differences between the efficiencies of utilization of diets were not statistically significant, but the values were highest with the diets containing added lipids.

Table 7. Mean heat production, energy and $N$ retentions of three sheep given the three diets, with standard errors of means

\begin{tabular}{|c|c|c|c|c|}
\hline Diet & $\begin{array}{c}\text { Level } \\
\text { of } \\
\text { feeding }\end{array}$ & $\begin{array}{c}\text { Heat } \\
\text { produced } \\
(\mathrm{kcal} / 24 \mathrm{~h})\end{array}$ & $\begin{array}{c}\text { Energy } \\
\text { retention } \\
(\mathrm{kcal} / 24 \mathrm{~h})\end{array}$ & $\begin{array}{c}\mathrm{N} \\
\text { retention } \\
(\mathrm{g} / 2 \mathrm{~h} \mathrm{~h})\end{array}$ \\
\hline Control & $\begin{array}{l}\text { Low } \\
\text { High }\end{array}$ & $\begin{array}{l}1793 \\
2377\end{array}$ & $\begin{array}{l}-300 \\
+705\end{array}$ & $\begin{array}{l}-1.39 \\
+2.06\end{array}$ \\
\hline Containing added glycerides & $\begin{array}{l}\text { Low } \\
\text { High }\end{array}$ & $\begin{array}{l}1788 \\
2416\end{array}$ & $\begin{array}{r}-108 \\
+1027\end{array}$ & $\begin{array}{r}-0.26 \\
+3.53\end{array}$ \\
\hline Containing added fatty acids & $\begin{array}{l}\text { Low } \\
\text { High }\end{array}$ & $\begin{array}{l}1818 \\
2487\end{array}$ & $\begin{array}{l}-125 \\
+985\end{array}$ & $\begin{array}{l}-0.21 \\
+430\end{array}$ \\
\hline SE of means & $\begin{array}{l}\text { Low } \\
\text { High }\end{array}$ & $\begin{array}{l} \pm 19 \\
\pm 43\end{array}$ & $\begin{array}{l} \pm 16^{*} \\
\pm 46^{*}\end{array}$ & $\begin{array}{l} \pm 0.42 \\
\pm 0.76\end{array}$ \\
\hline
\end{tabular}

Rapid infusion and continuous infusion of fatty acids. Fig. I shows the daily $\mathrm{CH}_{4}$ production of sheep $\mathrm{W}$ when given the same amount of linseed oil fatty acids either infused with the food or infused continuously into the rumen. Continuous slow infusion resulted in a lower rate of fall in daily $\mathrm{CH}_{4}$ production than rapid infusion with the food, and the mean amount produced in the period from the 8th to the 12 th day of infusion was $20.01 . / 24 \mathrm{~h}$, initial values for the 4 days before infusion being $26 \cdot 61 . / 24 \mathrm{~h}$. The fall of $6 \cdot 61 . \mathrm{CH}_{4}$ or $62 \cdot 7 \mathrm{kcal}$ from the $384 \mathrm{kcal}$ linseed oil fatty acids given was $16.3 \mathrm{kcal} / 100 \mathrm{kcal}$ fatty acids infused. Previous work with linolenic acid showed it to depress daily $\mathrm{CH}_{4}$ production by $\mathrm{I}^{6} \cdot 4 \pm \mathrm{r} \cdot 3 \mathrm{kcal} / \mathrm{I} 00 \mathrm{kcal}$ linolenic acid (Czerkawski et al. 1966). When the linseed oil fatty acids were infused rapidly, at I 1 . in $30 \mathrm{~min}, \mathrm{CH}_{4}$ production fell to the very low level of $10.01 . / 24 \mathrm{~h}$, but subsequently recovered to a mean value of $16 \cdot \mathrm{I} 1 . / 24 \mathrm{~h}$ for the last 4 days. The recovery coincided with a change in the sheep's eating behaviour. Individual meals, which normally were quickly consumed within the 30 min during which the rapid infusions were given, were partly refused at this time but were eaten completely later during the day or night. The depression of $\mathrm{CH}_{4}$ production measured from the last 4 days 
of the control period to the last 4 days of the infusion period was $x \mathrm{I} \cdot 371 . / 24 \mathrm{~h}$ or $\mathrm{r} 07.4 \mathrm{kcal} / 24 \mathrm{~h}$. The depression was $28.0 \mathrm{kcal} / \mathrm{roo} \mathrm{kcal}$ fatty acid infused. When linseed oil fatty acids were incorporated in the diet, the experiments with sheep $\mathrm{F}$, $\mathrm{E}$ and $\mathrm{B}$ showed $\mathrm{CH}_{4}$ production to be reduced by $28.9 \mathrm{kcal} / \mathrm{roO} \mathrm{kcal}$ fatty acid.

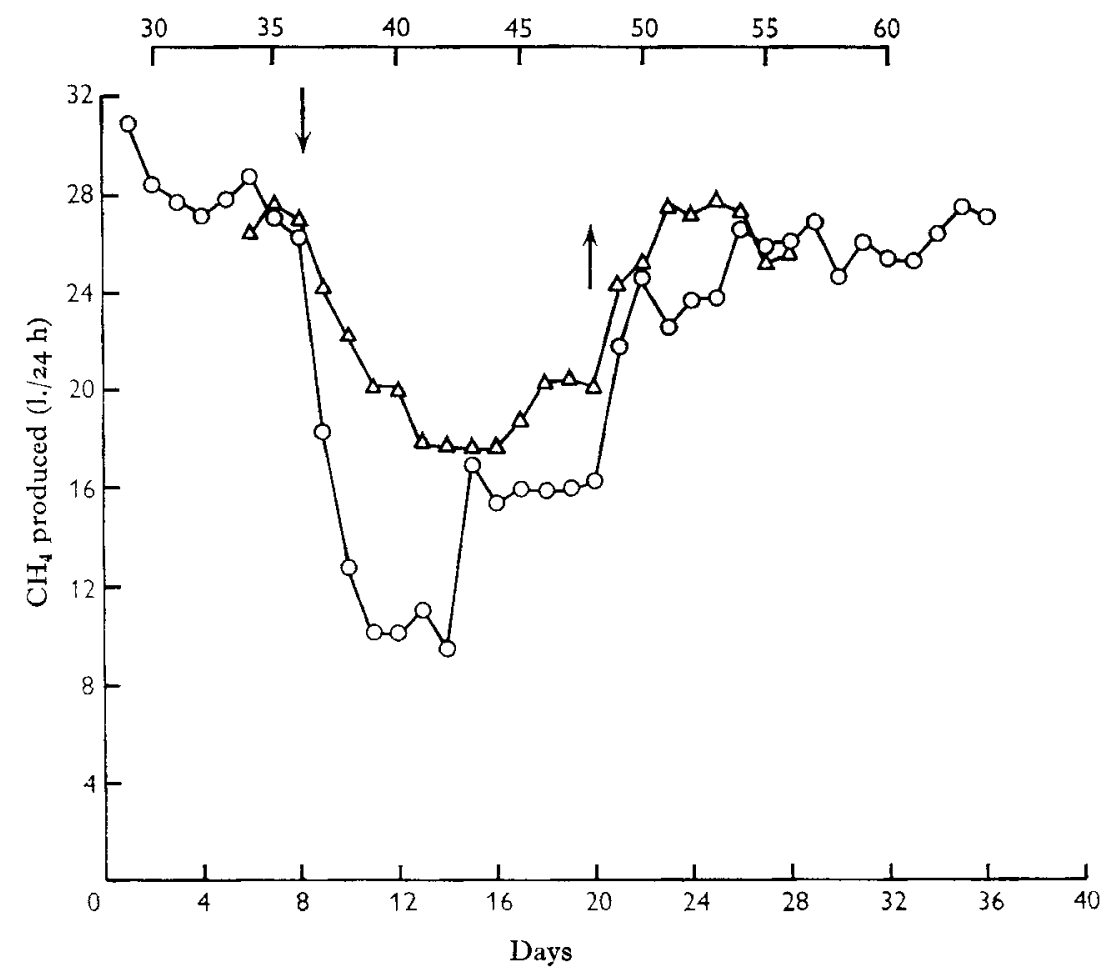

Fig. I. The effect of infusion of linseed oil fatty acids on methane production in sheep. $\triangle-\Delta$, slow continuous infusion of $60 \mathrm{~g}$ fatty acids $/ 24 \mathrm{~h}$ (time scale $30-60$ days), $0-0$, rapid twice daily infusion of $60 \mathrm{~g}$ fatty acids $/ 24 \mathrm{~h}$ (time scale $0-40$ days). Changes in the sheep's eating habits occurred on the Ist day in the latter experiment.

\section{DISCUSSION}

The results of the experiments show that the depression of $\mathrm{CH}_{4}$ production noted when linseed fatty acids, which largely consist of linolenic acid, were infused into the rumens of sheep receiving diets of dried grass can also be produced by incorporating the acids in a diet consisting mainly of cereals. The depressions of $\mathrm{CH}_{4}$ production observed when the fatty acids were incorporated in the diet and the diet was given twice daily were much greater than those noted when the fatty acids were infused at constant rates into the rumen of sheep given two meals of dried grass each day. The experiment with sheep $\mathrm{W}$ given a diet of dried grass in two meals showed that constant infusion of the fatty acids resulted in a depression of $\mathrm{CH}_{4}$ production which was indistinguishable from that noted with the same infusion technique and a similar diet in previous experiments (Czerkawski et al. 1966), namely I6.0 kcal/100 kcal fatty 
acid. Rapid infusion of the same amount of fatty acid at the times the animal was fed, however, resulted in a depression of $\mathrm{CH}_{4}$ production by $28 \mathrm{kcal} / \mathrm{I} 00 \mathrm{kcal}$ fatty acid, a value close to the $28.9 \mathrm{kcal} / \mathrm{roo} \mathrm{kcal}$ noted when the fatty acids were incorporated in the diet. It thus appears that the depression of $\mathrm{CH}_{4}$ production is a function of the concentration of fatty acids in the rumen at any one time rather than of the amounts of them that are given over $24 \mathrm{~h}$.

The organism which is of major importance in producing $\mathrm{CH}_{4}$ in the rumen is a Gram-positive chain-forming short rod Methanobacterium ruminatium (Smith \& Hungate, 1958; Bryant, 1965). Cellulolytic organisms are, by contrast, either neutral or very weakly positive to Gram's stain (Bryant, 1959). It seems possible that the greater effects of the fatty compounds on $\mathrm{CH}_{4}$ production than on cellulose digestion reflect differences in the behaviour of Gram-positive and Gram-negative organisms. Reviewing the literature on the effects of fatty acids on the growth of bacteria in vitro, Nieman (I954) concluded that 'generally only Gram-positive organisms are susceptible to the action of fatty acids in minute amounts'. He also concluded that inhibition of growth was caused by both saturated and unsaturated acids, that the effects of unsaturated acids increased with the number of double bonds they contained and that the effects of saturated acids were maximal when there were twelve or fourteen $\mathrm{C}$ atoms in the molecule. Such conclusions based on experiments in which the growth of Gram-positive organisms has been measured in vitro, agree with our findings in which the $\mathrm{CH}_{4}$ production of the sheep has been measured. Direct proof is clearly needed of the hypothesis that the fatty compounds exert their effects by inhibition of growth of Gram-positive methanogenic bacteria while allowing growth of cellulolytic bacteria.

\section{REFERENCES}

Blaxter, K. L. \& Clapperton, J. L. (1965). Br. F. Nutr. I9, 5 I I.

Bryant, M. P. (1959). Bact. Rev. 23, 125.

Bryant, M. P. (I965). In Physiology of Digestion in the Ruminant, p. 3II. [R. W. Dougherty, R. S.

Allen, W. Burroughs, N. L. Jacobsen and A. D. McGilliard, editors.] London: Butterworths.

Buysse, F. (1962). Revue Agric., Brux. 15, 343.

Czerkawski, J. W., Blaxter, K. L. \& Wainman, F. W. (r966). Br. F. Nutr. 20, 349.

Davison, K. L. \& Woods, W. (1960). F. Anim. Sci. r9, 54.

Davison, K. L. \& Woods, W. (I96I). F. Anim. Sci. 20, 532.

Davison, K. L. \& Woods, W. (1963a). F. Anim. Sci. 22, 9 I 9.

Davison, K. L. \& Woods, W. (1963b). F. Anim. Sci. 22, 27.

Esplin, G., Hale, W. H., Hubbert, F. Jr. \& Taylor, B. (1963). J. Anim. Sci. 22, 695.

Hungate, R. E. (1962). The Bacteria. Vol. 4, Ch. 3. [1. C. Gunsalus and R. Y. Stanier, editors.] London: Academic Press Inc.

Nieman, C. (1954). Bact. Rev. $\mathbf{8} 8$, I47.

Roberts, W. K. \& McKirdy, J. A. (1964). J. Anim. Sci. 23, 682.

Smith, P. H. \& Hungate, R. E. (1958). F. Bact. 75, 7 13.

Ward, J. K., Tefft, C. W., Sirny, R. J., Edwards, H. N. \& Tillman, A. D. (1957). F. Anim. Sci. 16, 633.

White, T. W., Grainger, R. B., Baker, F. H. \& Stroud, J. W. (1958). F. Anim. Sci. 17, 797. 